\title{
DISCOVERING THE ECOTOURISM PRODUCTS TO PROMOTE KAMPUNG SUNGAI YU AS A TOURISM DESTINATION
}

\author{
Munira Saaidin \\ Faculty of Business \& Technology, UNITAR International University, Malaysia
}

\begin{abstract}
The objective of the study is to assess the environmental area in Kampung Sungai $Y$, Hujong Permatang sub-district as a new ecotourism product. An analysis had been done on the resources available based on the environmental aspect to find a potential area that could be developed to become a new tourism attraction and product to the area. The data for this research was collected through several methods such as: observation, unstructured interviews, and secondary data from reliable sources. The research had been conducted for three (3) days in Kampung Sungai Yu and the overall area of Hujong Permatang. The four (4) elements that were used are community resources, site analysis, natural resources, and environmental assessment. The four (4) element used, is a guideline for the findings. From the findings, few potential places and potential product were able to be determined. Places such as the jetty of Kampung Sungai Yu, can be the main area where most of the activities and potential product are located. The potential products that are focus on related to the environment. Therefore, concept that should be adept is sustainable concept. It helps in preserving the potential product area. Potential tourism product such as bird watching, tuntong watching, sightseeing by experiencing from the fisherman boat, fishing, netting and also watching fireflies during the night relate closely to environment.
\end{abstract}

Key words: Natural, Environment, Kampung Sungai Yu, Tourism, ecotourism, product

Cite this Article: Munira Saaidin, Discovering the Ecotourism Products to Promote Kampung Sungai Yu as a Tourism Destination, International Journal of Management, 11(12), 2020, pp 1733-1741.

http://iaeme.com/Home/issue/IJM?Volume=11\&Issue=12

\section{INTRODUCTION}

Selangor, also known as the gateway to Malaysia due to its strategic location that connected to almost any major travelling route, is located at the west coast of Peninsular Malaysia. As the most developed state in Malaysia, Selangor is also the industrial hub of Malaysia. Despite 
being known as the most rapid developed state, Selangor are still blessed with different kinds of attraction from natural to man-made. Selangor is the most populated state in Malaysia with a population of 5.46 as of 2010. It shows that the most populated area in Selangor is the Federal Territory of Kuala Lumpur. Selangor which consists of nine (9) districts namely, Gombak, Klang, Kuala Langat, Kuala Selangor, Petaling, Sabak Bernam, Sepang, Ulu Langat, (Hulu Langat) and Ulu Selangor (Hulu Selangor).

Kuala Selangor is the second largest district in Selangor. Kuala Selangor got its named due to the Selangor river meets the sea, and 'Kuala' means 'river mouth' in Malay language. Kuala Selangor is also known as one of the Selangor's leading 'rice bowls' and it is rich for its historical background such as the first Selangor capital and old royal capital. There are consisting of nine (9) sub-districts that made up Kuala Selangor: Tanjong Karang, Hujong Permatang, Kuala Selangor, Ijok, Jeram, Bestari Jaya, Pasangan, Api-Api and Hulu Tinggi.

The area that was covered is Hujong Permatang. There are six (6) villages that are under the sub-district of Hujong Permatang, there are: Kampung Permatang, Kampung Ujong Permatang, Kampung Sungai Terap, Kampung Parit Serong, Kampung Sungai GulangGulang, and Kampung Sungai Yu. This research focus on Kampung Sungai Yu as it has the most potential reliable natural sources to be developed into a new tourism product.

Kampung Sungai $\mathrm{Yu}$ is at the very west of Hujong Permatang. Out of the six (6) villages, Kampung Sungai Yu covered the largest area in sub-district of Hujong Permatang. Kampung Sungai $\mathrm{Yu}$ is made up of different ethnic such as Malays, Javanese, Banjar and others. Kampung Sungai Yu has two (2) version of how it got its name. Sungai means river in Malay language. The first version is because of the river that took a shape of ' $U$ ' and that is why the name of the village is Sungai $\mathrm{Yu}$. The second version, there are sharks in the river. ' $\mathrm{Yu}$ ' means shark in Malay language. Plantation covers up most of the area. Types of plantation available in Kampung Sungai Yu are oil palm, banana, and sugar cane. The specialty of Kampung Sungai $\mathrm{Yu}$ is due to its location, it is near to the river mouth, therefore out of the entire village under Hujong Permatang, Kampung Sungai Yu is the only one that have jetty. The number of fishermen in Kampung Sungai Yu is around forty (40) people.

The purpose of the study is to develop a new tourism product from the existing of resources that are available in the area. The four (4) elements that were used to be focused on to assess in developing the new tourism product are community resources, site analysis, natural resources, and environmental assessment. From the elements that were focused on, Kampung Sungai Yu could be assess as a new potential product tourism in ecotourism due to its availability on the environment and natural resources. The objective of the research is to:

- To explore the environmental area in Kampung Sungai Yu.

- To assess the environmental area in Kampung Sungai Yu.

- To identify potential target market in new prospects for the new tourism product.

The significant of the research is to be able to create a product that could be useful for local community. The product should be resourceful and available to be obtain throughout the time. The product should be beneficial to the locals by creating income and generates economy in the local community system. The new product could also benefit other genre of people such as tourist, that will be able to learn and experiences by participating in activities that only could be offer in certain places. 


\section{RESEARCH FRAMEWORK}

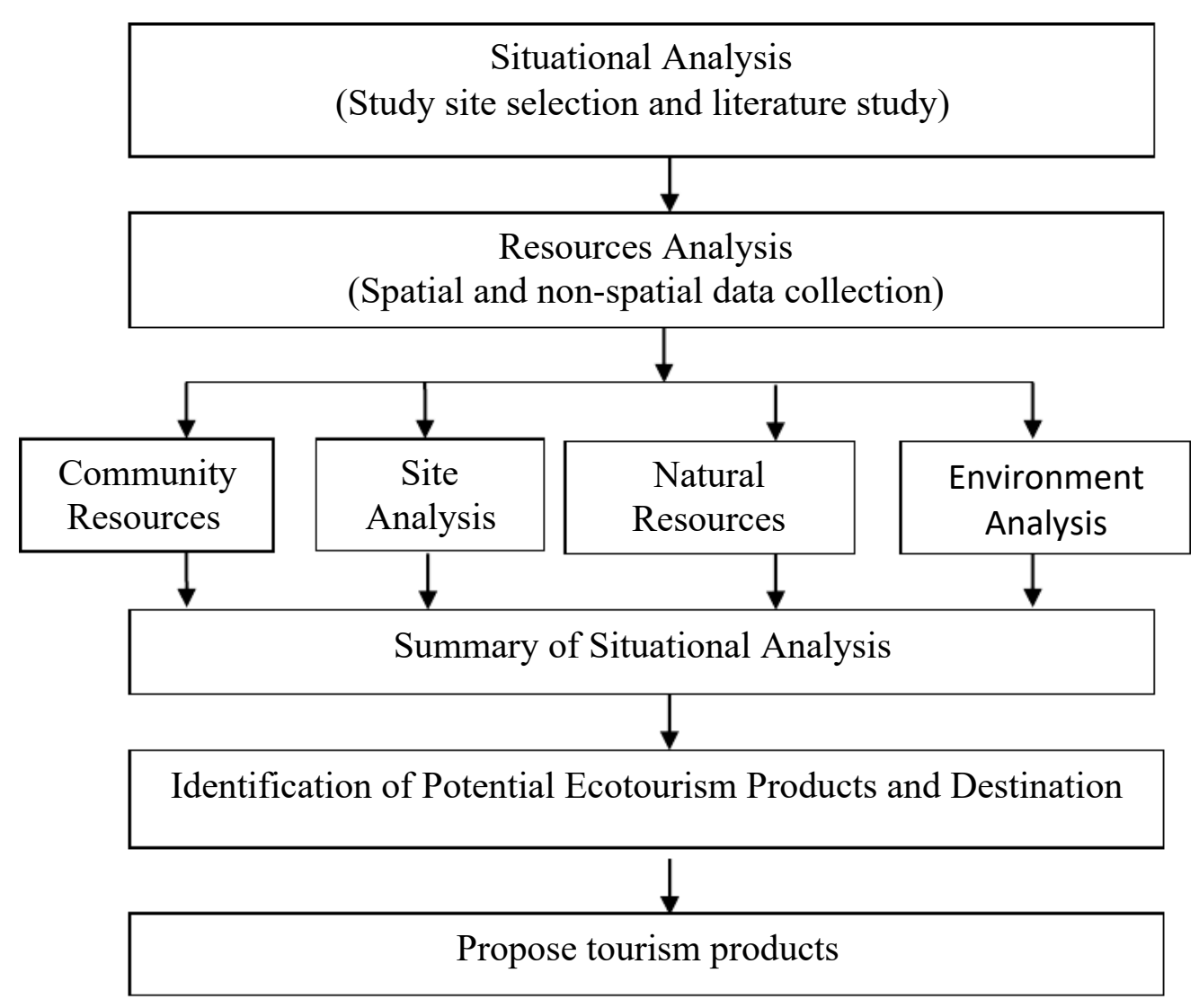

Figure 1 Conceptual framework for the study at Kampung Sungai Yu

\section{LITERATURE REVIEW}

Rural area has its own attraction in serving different kinds of tourism product or service. Such as Kampung Sungai $\mathrm{Yu}$ it has its own uniqueness that can attract outsider due to its resources. Such as even had been stated by Guo Huan-cheng and Liu Jun-Ping (2000) that more and more urban dwellers would like to visit countryside which can offer them pleasant rurality experiences. Most of Kampung Sungai $\mathrm{Yu}$ Resources is related to environment. Can environment be made as a tourism product? According to some, the relationship between tourism and the environment is a key feature to tourist selection (Yeoman, 2007). Marcouiller (1998) said that many points to the natural environment as a basis for a marketable tourism attraction or product. No matter what kind of place it is, tourism will be able to be adopt as long as it has resources that can be made into a tourism product.

A tourism product should be able to be used in a long term. Understanding and adapting sustainable concept in planning to develop a tourism area is important because, sustainable tourism meets the needs of the present without compromising the ability of future generation (Weaver, 2007). Therefore, adapting sustainability is important. The important of adapting sustainable tourism concept had been highlighted by Siti-Nabiha et. al. (2011) cited that sustainable tourism development has become an important criterion in attracting tourists.

The impact of ecotourism could be a good thing for the area that is going to be developing as an ecotourism area. Ideally ecotourism encourages natural resource conservation in return for 
local and national economic benefits, in addition to offering local, national and international tourists an opportunity to enjoy and learn about nature while respecting local culture (Brandon, 1996; Davenport et al., 2002; Emmons,1991; Honey, 1999).Other than that it could also create income to the community. Ecotourism, while promoting the conservation of natural areas that are tourist destinations, can provide economic revenues through entrance fees, employment of local residents of the park area, and tourist expenditures. Projects can generate foreign exchange and provide economic benefits to remote areas (Fennell, 1999). Ecotourism supports the synergic relationship between local people and tourism; constitutes the balance between the preservation and development; and it is an effective management supportive effort (Ross.et al. (1999). Therefore, Barnes et al., (1992) stated that ecotourism initiatives can attract investment capital for community infrastructure development, often including improved local social and educational services.

Ideally, ecotourism should satisfy several criteria such as conservation of biological and cultural diversities through ecosystem protection and promotion of sustainable use of biodiversity with minimal impact on the environment being a primary concern (Ryngnga $\mathrm{P}$. K, 2008).

\section{RESEARCH METHODOLOGY}

Research methodology is the methods that were used before, during and after the site visit and while writing the paper. It is used throughout the research paper. Knowing and identifying the research method can help in gathering info needed for the research. The research designs used to conduct this research are a combination of exploratory and descriptive. The exploratory study is used to explore and gain more information. It is used to discover new knowledge on an area to help with the research. It is mostly done by collecting primary data. While descriptive study is used to assess the research descriptively or in a much more detail mannered. The resources could be from secondary resources. It was deemed as the most appropriate method that could provide feedback in a concise manner and also and an economical way of collecting a large amount of data (Krathwohl,1998).

Basically, two principle means of data collection will be utilized: (1) Interview with local community, local and state authorities, government agencies and town councils, (2) Nonparticipative observation of natural resources, cultural resources, site analysis, community analysis, environment assessment, and tourism facilities and services.

\section{INSTRUMENT DEVELOPMENT}

The instruments that were used in this research is to help to assess the research in developing the new tourism product. The 4-instrument used are:

a) Community analysis checklist consists of 3 dimensions

i. Community ethnic background - to discover other different ethnic that made up the population of the area.

ii. Economic activity around residence -the availability of activities such as business, agriculture, fishing, farming and other.

iii. Community surrounding - is to discover if the place has an area like: beach, rural forest, town, suburb, jungle.

b) Site analysis consists of the following 6 dimensions:

i. Area economy - types of business or activities in the area, transportation availability.

ii. Availabilities of utilities 
iii. Visibility of area - road sign, indicated in the local map

iv. Pollution - types of pollution

v. Local labour

vi. Other services - such as police station, and mosque

c) Natural analysis checklist consists of 2 items to be evaluated. :

i. The availability of - beaches, coral reefs, mountains, forest reservation, waterfalls, lakes, river, and sea.

ii. To be able to relate the natural areas with its condition and the natural activities available.

d) Environment assessment involves the evaluation on following the 1 dimension with related features:

i. To observe for - potential ecological damage, pollutions, preservation need and other.

\section{FINDINGS}

The finding guidelines to assess within the village are usually been done base on the instrument that were listed above. The findings were put together based on during the course of exploration in the village by observing and interviews.

\subsection{Community Resources}

Kampung Sungai Yu is mostly made up of Malay that is mostly the descendent of Javanese and Banjar. However, estimated of $70 \%$ of Javanese descendent had preoccupied the area. By observing and interviews, the main locals' occupations are farmer, fisherman, fishmonger, and owner of their own business. Not for all, some local occupied themselves by having one to two (1-2) jobs. For example: during days that are impossible to get down to the sea, they occupied themselves with other jobs such as farming.

Farmers in Kampung Sungai Yu are usually occupied with working in their plantation. Such plantations that are available at Kampung Sungai $\mathrm{Yu}$ are oil palm plantation, banana plantation and sugar cane.

The number of fishermen in Kampung Sungai Yu is forty (40) peoples. The jetty in Kampung Sungai $\mathrm{Yu}$ is still in progress to be developing to increase and upgrade its facilities. The fisherman will work all days except for Friday because most of the fisherman's religion is Muslim. They will usually go to the sea early in the morning or in the evening. The catches that the get will be sell at the jetty by fishmonger or even the fisherman himself. The jetty can also be a place where the fisherman will gather together to have coffee, small talks and sometimes about the current issues among themselves. They also have a place where they repair the net by themselves by knitting the net that got torn or with big hole on it. Activity such as renting boat is also available at the jetty. For some fisherman, if they did not go to the sea that day, they will rent their boat to others.

\subsection{Site Analysis}

The area has good road foundation that connected to almost all the area in the village. The road conditions are also satisfying because it is mostly cover with tar. Transportation that is available is owned by the locals in the village. Mostly are motorcycles and cars. The accessibility for public transportation such as bus is only available from the main road which is outside of the village. 
The signage of Kampung Sungai Yu is small and vandalised. It makes it harder to be seen. The villager does not have any difficulties with utilities problem it seems that they were able to get electricity, water, and other supplies. From observation, pollution such as garbage, air and water pollution are not visible. All occupation and activities are done by the locals and are privately owned. Other services available are police station, which is nearby, jetty and mosque, in the Kampung Sungai Yu area.

The jetty of Kampung Sungai Yu is one of the places for people from outside Kuala Yu to come and buy their fish and seafood. The facility is a place for the fishmonger and the fisherman to sell their catches.

\subsection{Natural Resources}

Kampung Sungai Yu has lots of plantation. Types of plantation available are oil palm, sugar cane and banana. There are three (3) most common types of banana that were plant in the village. There are 'abu', 'montel' and 'berangan'. Some of the products are sold off to markets or many other areas, while some were used to make other product such banana snacks. Some product such as sugar cane are used to make sugar and only been sold to neighbouring country such as Singapore.

Kampung Sungai Yu have wild plants such as nipah trees (Nypa Fruticans), that produce fruits that could be sold and eat. It grows wild along the river to the open sea. Other trees that can be seen along the river are also mangrove trees (Rhizophora) and also berembang trees (Sonneratia caseolaris) which are also know for the trees that firefly like. Those trees are now had been preserve.

Natural resources such as beach are available. It is not the kind of beach that the locals able to go to. The location of the beach is at the backside of the village and the only way that are available to go there is by boat. The fisherman of Kampung Sungai Yu said that the beach is the place for Tuntong (Batagur baska), a type of long neck turtle, to lay eggs.

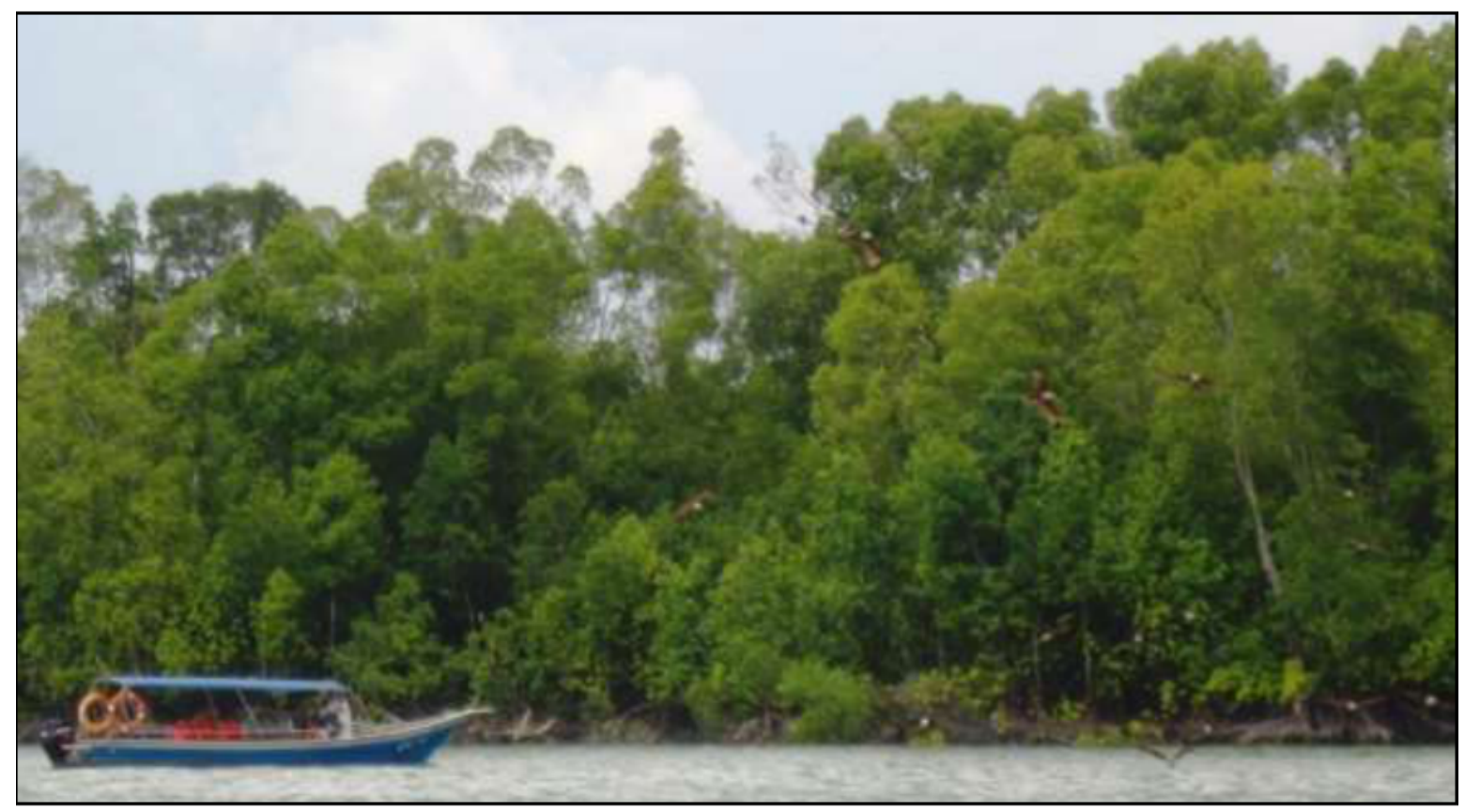

Figure 1 Feeding eagles from the boat 


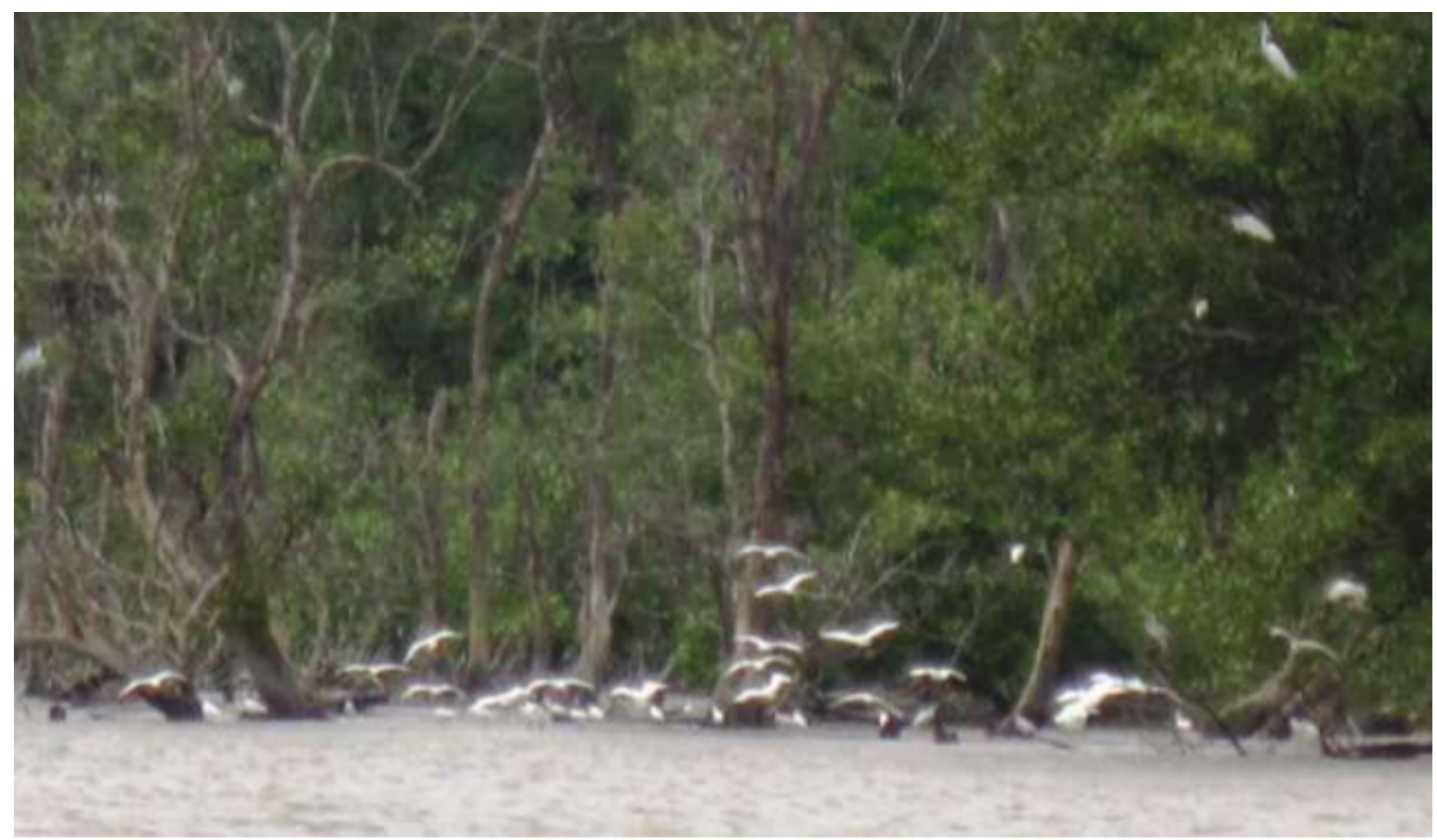

Figure 2 Migration of birds as seen from the boat

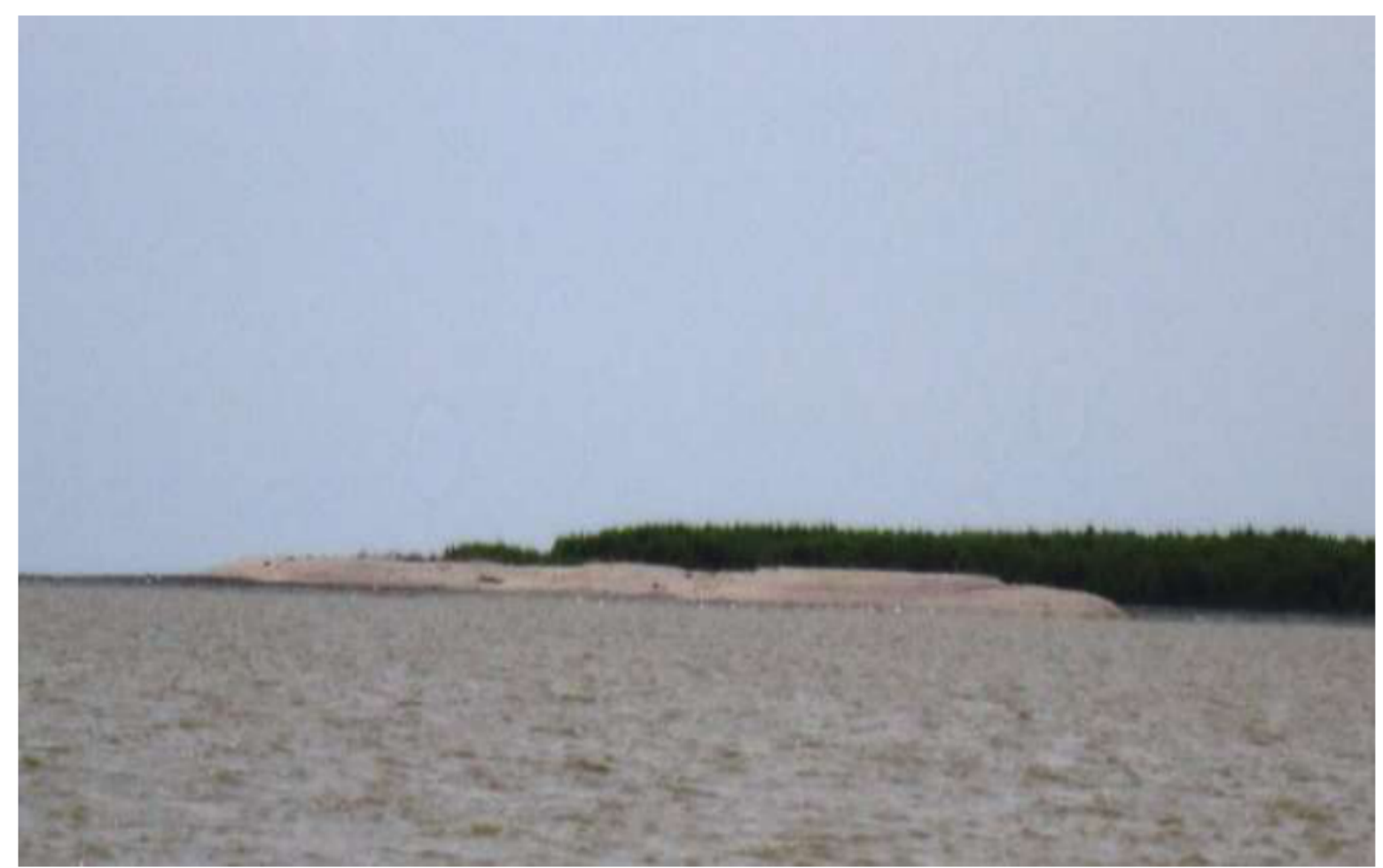

Figure 3 Spot at the beach where Tuntong lay eggs

The area is also known for birds: both locals and migration birds. The location to watch the birds are more visible from the river view. Just like the Tuntong, most of the fisherman knows the area where birds gather. Types of bird that can be seen are Eagle Winston (Haliaeetus leucocephalus), Flamingo (Phoenicopterus), and many other kinds of species. The perfect month to see migration bird is in October. This is because in October, birds from 
other places will migrate here due to the weather change. Activity such as feeding the eagles is available.

\subsection{Environmental Assessment}

Area such as mangrove and berembang trees need to be preserve due many different kinds of wildlife habitat depend on the plant. There were a lot of berembang trees along the river side, but due to making road for the fisherman to go out to the sea, the tree along the river from the jetty were cut down. Now only few are left to be preserve along with the mangrove trees. The local community pay attention to their surrounding needs. The preservation of mangroves and berembang trees come from effort put forth by the local community.

\section{RECOMMENDATION}

Kampung Sungai Yu could definitely be a tourist attraction due to its natural abundance. With a lot of potential sources that could be located in Kampung Sungai Yu, most of the sources are related to environment, greenery, natural, flora and fauna. The facilities that available could also contribute in enhancing the new product development. The local community also have contributed participated in preserving the natural resources. Environmental can be related closely to tourism.

Environment, natural greenery, flora, and fauna are resources that are vulnerable to small changes such as global warming, and pollution. It is much better to prevent from loss and damage then treating it in the future, which would cost more in time and money. To minimize the impact on the natural environment, it is better to adept the concept of sustainable. The concept of sustainable is a concept where it meets the need of the present time without compromising the future generation. This concept could be use in tourism by creating sustainable tourism.

Sustainable tourism and ecotourism are also a good concept because it encourages people to preserve the attraction area for the purpose of tourism. This could be said because tourism can stimulate the economy of the local area. By promoting Kampung Sungai $\mathrm{Yu}$ as a place that promotes ecotourism, it could bring benefit to the local community and also tourist. Benefit that it gives are awareness of sustaining, opportunity to learn new things, creating jobs which then relates to more income sources and thus generate the local economy. Generating local economy is important so that the area could be developed.

Activities related to environment that could be promote in Kampung Sungai Yu are: bird watching, Tuntong watching, fishing, netting, sightseeing by cruise on fisherman's boat, and by night, watching fireflies. This kind of activities attract different market segment. The type of tourist that would participate might mostly be special interest tourist such as photographer, anglers, bird lovers or nature lovers, students for educational purpose, family and much more.

The potential activities attempt to give full experiences which believe to give knowledge and experience in industry to the tourist. The area can be developed as a recreation place for local and tourist with lot of activities that ca be introduced such as "bubu" making (fish trap), making net and also day and night fishing. (Saaidin, M., 2012)

Kampung Sungai Yu could and should put more effort in promoting the village. Some of the ways to market the village to outsiders are by making it much more visible. Improve the signage by making it visible from the main road and clear signboard stating where the interest area is, in Kampung Sungai Yu. Upgrading more facilities such as boat with safety jacket, could also help in promoting the product. 


\section{CONCLUSION}

The research has proved that Kampung Sungai Yu could develop new tourism product based on environment assessment done on the area. The area uncovered has many potential in producing sustainable and ecotourism product from the available resources. From the helping hands of many, such as the community and the head villager, the village will be able to be known as one of the villages that provide ecotourism.

\section{REFERENCES}

[1] Barnes, J., Burgess, J. and Pearce, D. (1992) Wildlife tourism. In T.M. Swanson and E.B. Barbier (eds) Economics for the Wilds (pp. 136-51). London: Earthscan.

[2] Brandon, K. (1996) Ecotourism and Conservation: A Review of Key Issues. Washington, DC: World Bank.

[3] Davenport, L., Brockelman, W.Y., Wright, P.C., Ruf, K. and del Valle, F.B.R. (2002) Ecotourism tools for parks. In J. Terborgh, C. van Schaik, L. Davenport and M. Rao (eds) Making Parks Work: Strategies for Preserving Tropical Nature (pp. 279-306). Washington, DC: Island.

[4] Emmons, K. (1991) Educational planning and ecotourism: Targeting school students. In J.A. Kusler (ed.) Ecotourism and Resource Conservation: A Collection of Papers (vol. 2) (pp. 826-38). Wisconsin: Association of Wetland Managers.

[5] Fennell, D.A. (1999) Ecotourism: An Introduction. New York: Routledge.

[6] Guo Huan-Cheng, Liu Jun-Ping. (2000). Research on Agriculture Sightseeing Development (in Chinese). Economic Geography, Vol. 20, No. 2, Pg. 119-124. Retrieve on 12 March 2012

[7] Honey, M. (1999) Ecotourism and Sustainable Development: Who Owns Paradise? Washington, DC: Island.

[8] Krathwohl, D. R. (1998). Methods of educational and social science research: An integrated approach (2nd. ed.). New York: Longman.

[9] Marcouiller., and David, W. (1998). Environmental resources as latent primary factors of production in tourism: The case of forest-based commercial recreation. Journal of Tourism Economics 4(2), 131-145.

[10] Ross, S. and Wall, G., (1999). Ecotourism: Towards Congruence between Theory and Practice. Tourism Management, 20 (1), 123-132.

[11] Ryngnga P.K., (2008) Ecotourism Prioritization: A Geographic information system Approach.

[12] Saaidin, M. (2012). Discovering Ecotourism Products in the Community of Kampung Kempadang and Kampung Deraka. International Journal of Contemporary Research in Business. Vol 3, page $83-91$.

[13] Siti-Nabiha, A.K., N. Abdul Wahid, A. Amran, H. Che Haat \& I. Abustan. (2011). Towards A Sustainable Tourism Management In Malaysia, 301-310.

[14] Weaver, David. (2007). Emergence of sustainable tourism: Sustainable Tourism.

[15] Yeoman, Ian., Brass, D., and McMahon, U. (2007). Current issue in tourism: The authentic tourist, Journal of Tourism Management 2008, 1128-1138. 